\title{
GMR
}

\section{Estimates of genetics and phenotypics parameters for the yield and quality of soybean seeds}

E.V. Zambiazzi ${ }^{1}$, A.T. Bruzi ${ }^{1}$, S.R. Guilherme ${ }^{2}$, D.R. Pereira ${ }^{2}$, J.G. Lima ${ }^{2}$, A.M. Zuffo ${ }^{3}$, F. O. Ribeiro ${ }^{2}$, A.E.S. Mendes ${ }^{1}$, S.H.M. Godinho ${ }^{1}$ and M.L.M. Carvalho ${ }^{1}$

${ }^{1}$ Departamento de Agricultura, Universidade Federal de Lavras, Lavras, MG, Brasil

${ }^{2}$ Departamento de Biologia, Universidade Federal de Lavras, Lavras, MG, Brasil

${ }^{3}$ Departamento de Agronomia, Universidade Estadual do Mato Grosso do Sul, Cassilândia, MS, Brasil

Corresponding author: A.M. Zuffo

E-mail: alan_zuffo@hotmail.com

Genet. Mol. Res. 16 (3): gmr16039801

Received August 15, 2017

Accepted August 25, 2017

Published September 27, 2017

DOI http://dx.doi.org/10.4238/gmr16039801

Copyright (C) 2017 The Authors. This is an open-access article distributed under the terms of the Creative Commons Attribution ShareAlike (CC BY-SA) 4.0 License.

ABSTRACT. Estimating genotype x environment (GxE) parameters
for quality and yield in soybean seed grown in different environments
in Minas Gerais State was the goal of this study, as well as to evaluate
interaction effects of GxE for soybean seeds yield and quality. Seeds
were produced in three locations in Minas Gerais State (Lavras,
Inconfidentes, and Patos de Minas) in $2013 / 14$ and $2014 / 15$ seasons.
Field experiments were conducted in randomized blocks in a factorial
17 x 6 (GxE), and three replications. Seed yield and quality were
evaluated for germination in substrates paper and sand, seedling
emergence, speed emergency index, mechanical damage by sodium
hypochlorite, electrical conductivity, speed aging, vigor and viability
of seeds by tetrazolium test in laboratory using completely randomized
design. Quadratic component genotypic, GXE variance component,

Genetics and Molecular Research 16 (3): gmr16039801 
genotype determination coefficient, genetic variation coefficient and environmental variation coefficient were estimated using the Genes software. Percentage analysis of genotypes contribution, environments and genotype $\mathrm{x}$ environment interaction were conducted by sites combination two by two and three sites combination, using the R software. Considering genotypes selection of broad adaptation, TMG 1179 RR, CD 2737 RR, and CD 237 RR associated better yield performance at high physical and physiological potential of seed. Environmental effect was more expressive for most of the characters related to soybean seed quality. GxE interaction effects were expressive though genotypes did not present coincidental behavior in different environments.

Key words: Glycine max (L.) Merrill; Seed production; GxE; Genotype selection

\section{INTRODUCTION}

Soybean genotype selection main characteristics focus has been related to grain yield in recent years. However, this single character is not sufficient to increase added value for genotypes. In this sense, other characteristics of importance such as seed quality and resistance to major diseases are being required in addition to the productivity (Chiorato et al., 2010).

Different cultures selection is essential to meet growing demand for high yields, allowing the best genotypes selection of being capable to overcome productivity levels (Costa et al., 2004). Therefore, parameters estimation of different plant characteristics are important for having a selection relationship, in which, the greater the estimated value of a given parameter, the greater is the genotype choice success (Gravois and Bernhardt, 2000).

Genotype selection yield gain for productivity, agronomic traits, disease resistance (Leite et al., 2016), and soybean seeds quality (Vasconcelos et al., 2012) is reported in several studies. In addition, gain reports have been made in genotype selection in other crops, like common bean, hence, plant architecture productivity (Matos et al., 2007; Faria et al., 2014) and also for seeds quality (Perina et al., 2010). Phenotypic parameter estimation has been an important tool in genotypes superior selection; however, characteristics related to seed quality have not been very explored (Vasconcelos et al., 2012).

Seed production depends on genotypic potential essence and environment conditions in which it will develop (Valle and Simonetti, 2008). As seed production occurs in different environments, with edaphoclimatic variation conditions, which results in genotype and environment (GxE) interaction (Barros et al., 2010). This GxE interaction can be defined as differential genotype response when submitted to different environments (Allard and Bradshaw, 1964), and fundamental role is assumed in components demonstration and, therefore, should be estimated and considered in cultivars indication (Prado et al., 2001).

Considering soybean crop importance and demand for varieties with superior seeds quality and also more productive, knowledge techniques assist in genotype selection with favorable characteristics, as well as studying production environment contribution for seed quality. Parameter estimations were the object of this study related to soybean genotype seeds yield and quality grown in different environments in Minas Gerais State, as well as studying the effect of GxE interaction for soybeans seed yield and quality.

Genetics and Molecular Research 16 (3): gmr16039801 


\section{MATERIAL AND METHODS}

Field experiments were conducted in three different locations in Minas Gerais State 2013/2014 and 2014/2015 seasons. Experimental areas have an average altitude of 945, 940 and $955 \mathrm{~m}$ and soil classified as dystroferric red latosol, dystrophic red-yellow latosol and typical dystroferric red latosol for Patos de Minas, Inconfidentes, and Lavras, respectively. The monthly climatological data was obtained during experiments conductions and are presented in Figure 1.
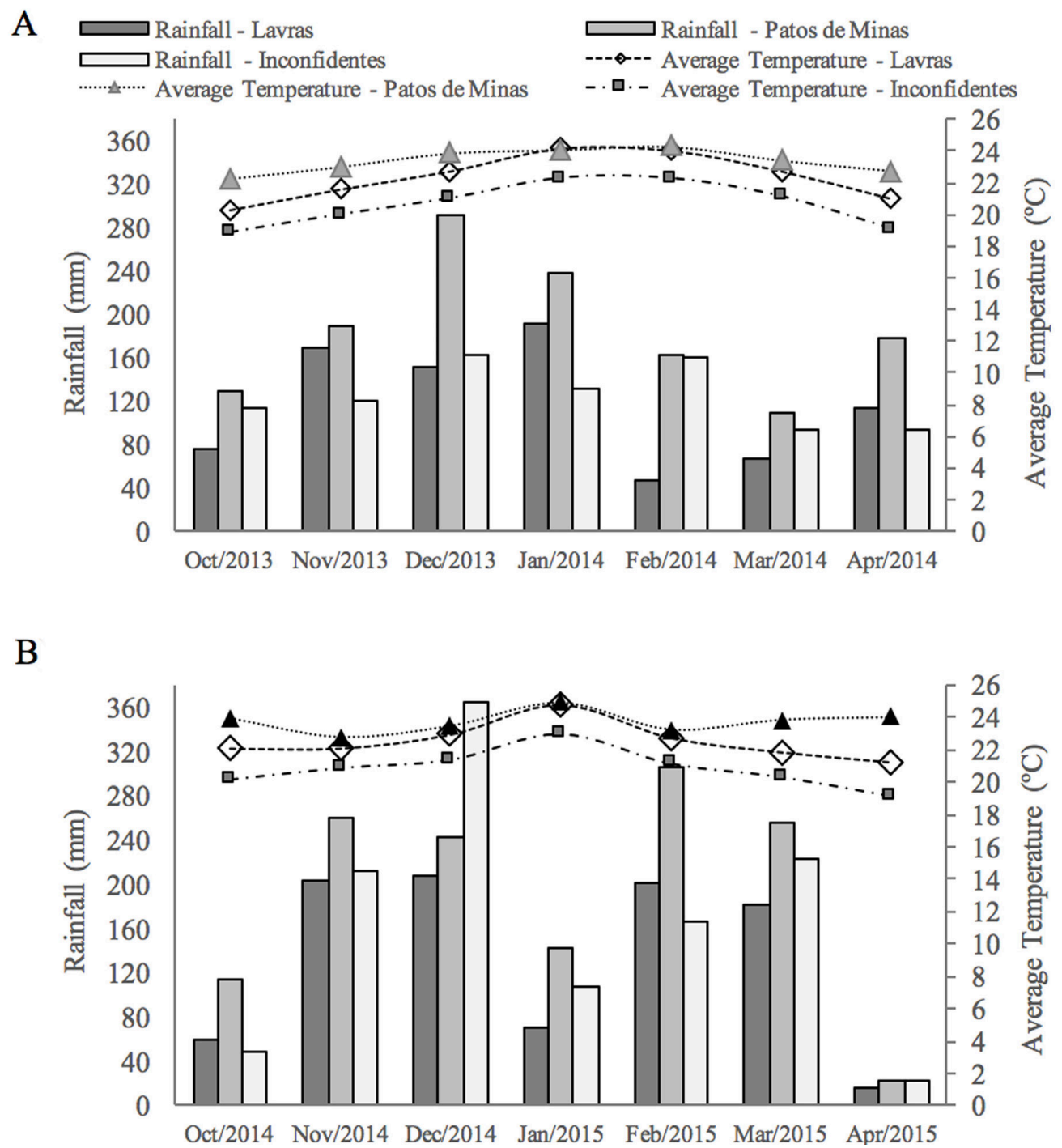

Figure 1. Monthly average rainfall $(\mathrm{mm})$ and average temperature $\left({ }^{\circ} \mathrm{C}\right)$, has occurred in Lavras, Patos de Minas and Inconfidentes in Minas Gerais State in 2013/14 (A) and 2014/15 (B) seasons, during the experiments. 
Experimental design was completed randomized block design in a factorial 17 x 6 (GxE), and three replications. The soybean cultivars, used in the experiment and there main characteristics are presented in Table 1. The experimental plots and useful area consisted of two lines of $5.0 \mathrm{~m}$ in length, spaced at $0.50 \mathrm{~m}$. Experiments were conducted in a no-tillage area system over maize stubble, under previous area burndown by $960 \mathrm{~g} / \mathrm{ha}$ glyphosate active ingredient. Recommendations of Souza and Lobato (2004) were followed for fertilization, being applied $350 \mathrm{~kg} / \mathrm{ha}$ of formulated N-P2O5-K2O (02-30-20) in-furrow.

Manual seedling was conducted with 15 seeds density per linear meter. Inoculation was carried out after seeding in-furrow, according to Embrapa (2013) recommendations and Bradyrhizobium japonicum bacteria in $18 \mathrm{~mL}$ comercial product $/ \mathrm{kg}$ seed dosage - SEMIA strains 5079 and 5080, containing $10.8 \times 10^{6} \mathrm{CFU} /$ Nitragin Cell Tech inoculant seeds $\mathrm{HC}^{\circledR}$ $\left(3 \times 10^{9} \mathrm{CFU} / \mathrm{mL}\right)$. Weed control, pests and diseases were carried out according to technical recommendations suitable for soybean cultivation (Embrapa, 2013).

Table 1. Origin and some characteristics of the genetic materials used in the experiment.

\begin{tabular}{l|l|c|c|c}
\hline Genetic materials & Origin & MG & GH \\
\hline 1 & BMX Força RR & Brasmax & 6.2 & Indeterminate \\
\hline 2 & BMX Potência RR & Brasmax & 7.0 & Indeterminate \\
\hline 3 & BRS MG 760 SRR & Embrapa & 7.6 & Indeterminate \\
\hline 4 & BRS MG 780 RR & Embrapa & 7.8 & Determinate \\
\hline 5 & CD 237 RR & Coodetec & 8.1 & Determinate \\
\hline 6 & CD 250 RR & Coodetec & 5.5 & Indeterminate \\
\hline 7 & CD 2737 RR & Coodetec & 7.3 & Indeterminate \\
\hline 8 & M7211 RR & Monsoy & 7.2 & Indeterminate \\
\hline 9 & NA 5909 RG & Nidera & 6.1 & Indeterminate \\
\hline 10 & NA 7200 RR & Nidera & 7.2 & Indeterminate \\
\hline 11 & NS 7100 RR & Nidera & 7.2 & Determinate \\
\hline 12 & P 98Y11 RR & Du Pont Pioneer & 8.1 & Determinate \\
\hline 13 & TMG 1176 RR & TMG & 7.6 & Determinate \\
\hline 14 & TMG 1179 RR & TMG & 7.9 & Determinate \\
\hline 15 & TMG 1181 RR & TMG & 7.1 & Determinate \\
\hline 16 & TMG 123 RR & TMG & 6.2 & Indeterminate \\
\hline 17 & Vmax RR & Syngenta & & \\
\hline
\end{tabular}

$\mathrm{MG}=$ Maturity group; $\mathrm{GH}=$ Growth habit.

Harvesting was performed manually when plants reached R8 stage - full maturation (Fehr et al., 1971), and threshing was performed mechanically by MAQTRON ${ }^{\circledR}$ Vencedora model B - 350 STD plot thresher. From the plots areas were estimated seed yield in $\mathrm{kg} / \mathrm{ha}$, corrected to $13 \%$ moisture. For analyses and determinations, seeds retained in sieves of circular rim 6.5 and $7 \mathrm{~mm}$ were used. Laboratory evaluations were conducted by a completely randomized design and two replications of 50 seeds from each field plot.

For seed quality evaluations, we submitted: Germination: performed accordingly to Brasil (2009) substrate paper and sand evaluation; seedling emergence: seeding was performed in plastic trays containing as substrate soil + sand, ratio $2: 1$, moistened at $60 \%$ of hold capacity - trays were kept in a chamber at $25^{\circ} \mathrm{C}$ temperature and 12 -h photoperiod, with daily evaluations regarding normal seedling emergence and final count at 14 days after seeding. Final percentage of emergence and emergence speed rate were considered, IVE (Maguire, 1962); electrical conductivity: according Castro et al. (2017) and support of conductivity meter was performed (MS TECNOPON ${ }^{\circledR}$ - mCA150), and expressed results in $\mu \mathrm{S} \cdot \mathrm{cm}^{-1} \mathrm{~g}^{-1}$; aging speed, having plastic boxes gerbox type adapted with screen suspended aluminum. In each gerbox, it was added $40 \mathrm{~mL}$ water and one seed single layer over the entire screen. Then,

Genetics and Molecular Research 16 (3): gmr16039801 
they were kept in BOD chamber at $41{ }^{\circ} \mathrm{C}$ for $48 \mathrm{~h}$ (Castro et al., 2017). Seeds were submitted to the germination test after this period (Brasil, 2009). Tetrazolium test: seeds were placed between moist paper for $16 \mathrm{~h}$ at $25^{\circ} \mathrm{C}$ and then immersed in tetrazolium chloride solution (2, 3,5 triphenyl tetrazolium chloride) until $0.075 \%$, in which seeds remained for $3 \mathrm{~h}$ at $40^{\circ} \mathrm{C}$, in light absence. The result was expressed by vigor percentage and viability (verified in levels 1 to 8), as França Neto et al. (1998). Mechanical damage: by sodium hypochlorite test according to criteria described by Krzyzanowski et al. (2004). Samples were placed in a container and immersed in sodium hypochlorite solution for $10 \mathrm{~min}$. Then, seeds were placed on tower paper sheets, and then, seed numbers were analyzed by broken coat and loose ones. Results are reported as seed percentage with mechanical damage.

Analysis of joint and individual variance was performed by statistical model and review procedure similar to that presented by Ramalho et al. (2012a), and when averages were significant, they were grouped by Scott-Knott test (Scott and Knott, 1974) at 5\% probability. Experimental precision was performed by accuracy selective estimates (rgg'). Quadratic component genotypic, genotypic variance component GxE, coefficient of determination, genotypic coefficient of genetic variation, and the coefficient of environmental variation were estimated. Genetic and phenotypic parameters estimates were obtained with the Genes software (Cruz, 2013). Percentage analysis of genotypes contribution, environments, and GxE interaction were conducted by site combination two by two and three-site combination, with software R (R Development Core Team, 2015).

\section{RESULTS AND DISCUSSION}

According to analysis of variance (Table 2) significant differences $(\mathrm{P} \leq 0.05)$, physiological potential of soybean seeds were found between genotypes and environments production. Differentiated performance against environmental variations was indicated by cultivars presented though caused by location or crop seed production. GxE interaction

Table 2. Summary of joint variance analysis of yield data (Y), germination (G), sand germination (SG), seedling emergency (SE), emergence speed index (ESI), eletrical conductivity (EC), aging speed (AS), vigor (VIG), and viability (VIA) of seeds by tetrazolium test and mechanical damage by sodium hypochlorite test (MD - \%) in soybean genotype seeds evaluated in different environments in Minas Gerais State, Brazil.

\begin{tabular}{|c|c|c|c|c|c|c|}
\hline \multirow[t]{2}{*}{ SV } & \multirow[t]{2}{*}{ d.f. } & \multicolumn{5}{|c|}{ prob $>$ Fc } \\
\hline & & $\mathrm{Y}$ & $\mathrm{G}$ & SG & SE & ESI \\
\hline Genotypes (G) & 16 & $* *$ & $*$ & $*$ & * & $* *$ \\
\hline Environment (E) & 5 & $* *$ & $* *$ & $* *$ & $* *$ & $* *$ \\
\hline $\mathrm{G} \times \mathrm{E}$ & 80 & $* *$ & $* *$ & $* *$ & $* *$ & $* *$ \\
\hline Residual & $202^{\mathrm{a} / 204^{\mathrm{b}}}$ & - & - & - & - & - \\
\hline General Average & & 2831.10 & 75.60 & 81.50 & 88.90 & 56.30 \\
\hline Accuracy (\%) & & 86.11 & 72.83 & 67.12 & 68.00 & 76.03 \\
\hline \multirow[t]{2}{*}{ SV } & \multirow[t]{2}{*}{ d.f. } & \multicolumn{5}{|c|}{ prob $>$ Fc } \\
\hline & & $\mathrm{EC}$ & AS & VIG & VIA & MD \\
\hline Genotypes (G) & 16 & NS & $* *$ & $*$ & NS & $* *$ \\
\hline Environment (E) & 5 & $* *$ & $* *$ & ** & $* *$ & $* *$ \\
\hline $\mathrm{G} \times \mathrm{E}$ & 80 & $* *$ & $* *$ & $* *$ & $* *$ & $* *$ \\
\hline Residual & $202^{\mathrm{a} / 204^{\mathrm{b}}}$ & - & - & - & - & - \\
\hline General Average & & 54.10 & 53.40 & 75.00 & 86.10 & 8.80 \\
\hline Accuracy $(\%)$ & & 64.16 & 84.79 & 69.22 & 40.82 & 75.30 \\
\hline
\end{tabular}

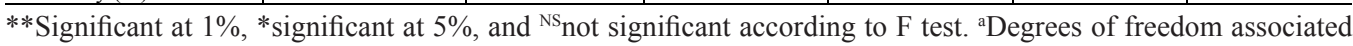
to error of analysis performed in DBC; b degree of freedom associated to error of analysis performed in DIC. SV $=$ source of variation; d.f. = degree of freedom.

Genetics and Molecular Research 16 (3): gmr16039801 
was significant for all traits evaluated (Table 2), showing different genotypes behavior in environments evaluated.

GxE interactions are often reported in soybean seeds quality evaluation (Zambiazzi et al., 2014; Monteiro et al., 2016; Castro et al., 2017). It was observed a better productive performance for TMG 1179 RR, NA 7200 RR, CD 2737 and CD 237 RR genotypes respectively by considering a broad adaptability (Table 3 ). In addition, seed industry requires a broad and severe internal system quality control to obtaining high yields and minimum standards for seed marketing, preserving genetic purity and physical quality characteristics, physiological and sanitary, keeping high germination and seeds vigor interesting to the farmer (França Neto, 2016).

Table 3. Mean values of yield (Y, kg/ha), germination ( $\mathrm{G}, \%)$, sand germination (SG, \%), seedling emergence (SE, $\%$ ), emergence speed index (ESI), electrical conductivity $\left(\mathrm{EC}, \mu \mathrm{S} \cdot \mathrm{cm}^{-1} \cdot \mathrm{g}^{-1}\right)$, aging speed (AS, \%), vigor (VIG, \%), and viability (VIA, \%) of seeds by tetrazolium test and mechanical damage by sodium hypochlorite test (MD, \%) in soybean genotype seeds (GEN) evaluated in different environments in Minas Gerais State, Brazil.

\begin{tabular}{|c|c|c|c|c|c|c|c|c|c|c|}
\hline GEN & $\mathrm{Y}$ & G & SG & SE & ESI & EC & AS & VIG & VIA & MD \\
\hline 1 & $2903.3^{\mathrm{b}}$ & $77.0^{\mathrm{b}}$ & $83.0^{\mathrm{b}}$ & $89.0^{\mathrm{b}}$ & $57.4^{\mathrm{b}}$ & $53.7^{\mathrm{b}}$ & $51.0^{\mathrm{d}}$ & $74.0^{\mathrm{c}}$ & $86.0^{\mathrm{a}}$ & $9.0^{\mathrm{b}}$ \\
\hline 2 & $2937.1^{b}$ & $80.0^{\mathrm{b}}$ & $84.0^{\mathrm{b}}$ & $93.0^{\mathrm{a}}$ & $59.3^{\mathrm{b}}$ & $48.1^{\mathrm{c}}$ & $54.0^{\mathrm{c}}$ & $78.0^{\mathrm{a}}$ & $89.0^{\mathrm{a}}$ & $8.0^{\mathrm{b}}$ \\
\hline 3 & $3006.1^{b}$ & $74.0^{\mathrm{c}}$ & $81.0^{\mathrm{b}}$ & $89.0^{\mathrm{b}}$ & $54.6^{\mathrm{c}}$ & $50.0^{c}$ & $54.0^{\mathrm{c}}$ & $74.0^{\mathrm{c}}$ & $85.0^{\mathrm{a}}$ & $9.0^{\mathrm{b}}$ \\
\hline 4 & $2735.1^{\mathrm{b}}$ & $73.0^{\mathrm{c}}$ & $81.0^{\mathrm{b}}$ & $90.0^{\mathrm{b}}$ & $55.2^{\mathrm{c}}$ & $54.8^{\mathrm{b}}$ & $50.0^{\mathrm{d}}$ & $73.0^{c}$ & $87.0^{\mathrm{a}}$ & $9.0^{\mathrm{b}}$ \\
\hline 5 & $3128.8^{a}$ & $82.0^{\mathrm{a}}$ & $87.0^{\mathrm{a}}$ & $93.0^{\mathrm{a}}$ & $60.2^{\mathrm{a}}$ & $51.5^{\mathrm{c}}$ & $62.0^{\mathrm{b}}$ & $79.0^{\mathrm{a}}$ & $87.0^{\mathrm{a}}$ & $5.0^{\mathrm{a}}$ \\
\hline 6 & $2264.0^{\mathrm{c}}$ & $65.0^{\mathrm{d}}$ & $69.0^{\mathrm{e}}$ & $81.0^{\mathrm{d}}$ & $50.0^{\mathrm{d}}$ & $60.2^{\mathrm{a}}$ & $37.0^{\mathrm{f}}$ & $70.0^{\mathrm{d}}$ & $82.0^{\mathrm{b}}$ & $15.0^{\mathrm{d}}$ \\
\hline 7 & $3162.8^{\mathrm{a}}$ & $83.0^{\mathrm{a}}$ & $88.0^{\mathrm{a}}$ & $94.0^{\mathrm{a}}$ & $61.5^{\mathrm{a}}$ & $48.9^{\mathrm{c}}$ & $59.0^{\mathrm{c}}$ & $79.0^{\mathrm{a}}$ & $88.0^{\mathrm{a}}$ & $7.0^{\mathrm{b}}$ \\
\hline 8 & $2889.4^{b}$ & $79.0^{\mathrm{b}}$ & $83.0^{\mathrm{b}}$ & $90.0^{\mathrm{b}}$ & $57.4^{\mathrm{b}}$ & $53.9^{\mathrm{b}}$ & $57.0^{\mathrm{c}}$ & $77.0^{\mathrm{b}}$ & $88.0^{\mathrm{a}}$ & $8.0^{\mathrm{b}}$ \\
\hline 9 & $2669.0^{b}$ & $75.0^{\mathrm{c}}$ & $81.0^{\mathrm{b}}$ & $87.0^{\mathrm{c}}$ & $55.1^{\mathrm{c}}$ & $54.6^{\mathrm{b}}$ & $53.0^{\mathrm{c}}$ & $76.0^{b}$ & $86.0^{\mathrm{a}}$ & $9.0^{\mathrm{b}}$ \\
\hline 10 & $3343.3^{a}$ & $68.0^{\mathrm{d}}$ & $75.0^{\mathrm{d}}$ & $83.0^{\mathrm{d}}$ & $52.0^{\mathrm{d}}$ & $59.2^{\mathrm{a}}$ & $46.0^{\mathrm{e}}$ & $68.0^{\mathrm{d}}$ & $82.0^{\mathrm{b}}$ & $11.0^{\mathrm{c}}$ \\
\hline 11 & $1998.3^{\mathrm{c}}$ & $72.0^{\mathrm{c}}$ & $79.0^{c}$ & $89.0^{\mathrm{b}}$ & $55.9^{\mathrm{c}}$ & $55.5^{\mathrm{b}}$ & $45.0^{\mathrm{e}}$ & $75.0^{\mathrm{b}}$ & $87.0^{\mathrm{a}}$ & $12.0^{\mathrm{c}}$ \\
\hline 12 & $3056.0^{b}$ & $80.0^{\mathrm{b}}$ & $85.0^{\mathrm{a}}$ & $91.0^{\mathrm{b}}$ & $58.2^{\mathrm{b}}$ & $49.6^{\mathrm{c}}$ & $63.0^{\mathrm{b}}$ & $76.0^{b}$ & $87.0^{\mathrm{a}}$ & $8.0^{\mathrm{b}}$ \\
\hline 13 & $2855.9^{b}$ & $71.0^{\mathrm{c}}$ & $79.0^{\mathrm{c}}$ & $87.0^{\mathrm{c}}$ & $52.3^{\mathrm{d}}$ & $60.3^{\mathrm{a}}$ & $56.0^{\mathrm{c}}$ & $74.0^{\mathrm{c}}$ & $86.0^{\mathrm{a}}$ & $8.0^{\mathrm{b}}$ \\
\hline 14 & $3498.4^{a}$ & $83.0^{\mathrm{a}}$ & $88.0^{\mathrm{a}}$ & $93.0^{\mathrm{a}}$ & $61.0^{\mathrm{a}}$ & $49.7^{\mathrm{c}}$ & $68.0^{\mathrm{a}}$ & $80.0^{\mathrm{a}}$ & $89.0^{\mathrm{a}}$ & $6.0^{\mathrm{a}}$ \\
\hline 15 & $2571.6^{c}$ & $86.0^{\mathrm{a}}$ & $89.0^{\mathrm{a}}$ & $93.0^{\mathrm{a}}$ & $62.8^{\mathrm{a}}$ & $50.6^{\mathrm{c}}$ & $65.0^{\mathrm{b}}$ & $79.0^{\mathrm{a}}$ & $88.0^{\mathrm{a}}$ & $5.0^{\mathrm{a}}$ \\
\hline 16 & $2289.0^{c}$ & $72.0^{\mathrm{c}}$ & $81.0^{\mathrm{b}}$ & $87.0^{\mathrm{c}}$ & $54.5^{\mathrm{c}}$ & $62.3^{\mathrm{a}}$ & $49.0^{\mathrm{d}}$ & $75.0^{\mathrm{b}}$ & $86.0^{\mathrm{a}}$ & $11.0^{\mathrm{c}}$ \\
\hline 17 & $2820.7^{b}$ & $67.0^{\mathrm{d}}$ & $74.0^{\mathrm{d}}$ & $84.0^{\mathrm{d}}$ & $50.3^{\mathrm{d}}$ & $58.3^{\mathrm{a}}$ & $39.0^{f}$ & $69.0^{\mathrm{d}}$ & $82.0^{\mathrm{b}}$ & $12.0^{\mathrm{c}}$ \\
\hline
\end{tabular}

Averages followed by same letter do not differ between each other, at $5 \%$ probability by Scott Knott test.

Accordingly to normative instruction No. 45 (Brasil, 2013) percentage germination required for seed marketing in Brazil is $80 \%$. High germination rates provide a required plant population, which is a key aspect to achieving high levels of productivity (Krzyzanowski, 2004). In contrast, seed germination percentage below minimum required for marketing, results in seedlings without possibility of establishing competitively in the field (França Neto et al., 2010).

It was inferred that genotype seeds BMX Potência RR, CD 237 RR, CD 2737 RR, P 98Y11 RR, TMG 1179 RR, and TMG 1181 RR presented superior potential in relation to other cultivars, associating better quality by vigor evaluations and seeds viability, and also lower mechanical damage rates. The genotype TMG 1181 RR although presented high seed quality, did not present good yield. In this way, it was possible to associate, in some cases, the relation of genotypes with high yields and high physiological potential. This is an important factor that contributes to and may favor this event, is related to the use of appropriate genotypes, which adapt to the region of production to obtain high yields (França Neto et al., 2013).

In relation to genetic and phenotypic parameters estimated, quadratic component expresses existing genotypic variability when working with fixed effect (Cruz, 2005). Considering joint environmental analysis, it was observed quadratic component genotypic estimates were lower than the variance component GxE and environmental variance for all traits evaluated (Table 4). Variation observed indicated for these parameters, for most part has been due to environmental effects.

Genetics and Molecular Research 16 (3): gmr16039801 
Table 4. Estimated parameters from environment joint analysis, from variables yield ( $\mathrm{Y}, \mathrm{kg} / \mathrm{ha})$, germination $(\mathrm{G}$, $\%$ ), sand germination (SG, \%), seedling emergence (SE, \%), emergence speed index (ESI), electrical conductivity $\left(\mathrm{EC}, \mu \mathrm{S} \cdot \mathrm{cm}^{-1} \cdot \mathrm{g}^{-1}\right)$, aging speed (AS, \%), vigor (VIG, \%), and viability (VIA, \%) of seeds by tetrazolium test and mechanical damage by sodium hypochlorite test (MD, \%) in soybean genotype seeds evaluated in different environments in Minas Gerais State, Brazil.

\begin{tabular}{l|c|c|c|c|c|c|c}
\hline & $\mathrm{QC}_{\mathrm{G}}$ & $\mathrm{VC}_{\mathrm{G} \times \mathrm{E}}$ & $\mathrm{R} . \mathrm{V}$. & $\mathrm{DC}_{\mathrm{G}}(\%)$ & $\mathrm{GCV}(\%)$ & CEv (\%) & $\begin{array}{c}\text { Ratio } \\
\text { DCg/CEv }\end{array}$ \\
\hline $\mathrm{Y}$ & $112,235.8$ & $84,935.3$ & $431,456.2$ & 74.2 & 11.8 & 23.2 & 0.5 \\
\hline $\mathrm{G}$ & 20.4 & 93.3 & 25.8 & 53.2 & 6.0 & 6.7 & 0.9 \\
\hline $\mathrm{SG}$ & 13.2 & 83.4 & 21.8 & 45.3 & 4.5 & 5.7 & 0.8 \\
\hline SE & 6.8 & 39.0 & 16.4 & 46.3 & 2.9 & 4.5 & 0.6 \\
\hline ESI & 8.7 & 30.0 & 17.9 & 57.9 & 5.2 & 7.5 & 0.7 \\
\hline EC & 8.5 & 57.0 & 35.9 & 41.2 & 5.4 & 11.0 & 0.5 \\
\hline AS & 54.8 & 104.0 & 52.7 & 72.0 & 13.9 & 13.5 & 1.0 \\
\hline VIG & 6.0 & 30.4 & 19.2 & 48.0 & 3.3 & 5.8 & 0.6 \\
\hline VIA & 0.8 & 19.2 & 14.0 & 16.9 & 1.1 & 4.4 & 0.2 \\
\hline MD & 3.8 & 14.1 & 6.9 & 56.8 & 21.9 & 29.5 & 0.7 \\
\hline
\end{tabular}

$\mathrm{QC}_{\mathrm{G}}=$ quadratic component genotypic; $\mathrm{VC}_{\mathrm{GxE}}=$ component of variance $\mathrm{GxE} ; \mathrm{R} . \mathrm{V}$. = residual variance; $\mathrm{DC}_{\mathrm{G}}=$ genotypic determination coefficient; $\mathrm{GCv}=$ genetic coefficient of variation; $\mathrm{CEv}=$ coefficient of environmental variation.

Genotype coefficient determination is a parameter related to heritability and its greater importance is connected to a predictive function expressing confidence of phenotypic value as genetic guide or degree correspondence between phenotypic and genetic values (Ramalho et al., 2012b). Estimates of genotypic determination coefficient corroborate with estimates observed for components genotypic quadratic, since estimates obtained were of low to medium magnitude, ranging from 16.9 to $74.2 \%$ (Table 4). Consistent values were only observed for productivity $(74.2 \%)$ and for vigor test carried out by aging speeding test $(72.0 \%)$. From all variation observed in these characteristics, approximately half of them are from genetic origin and the other part possibly related to environment effects or experimental deviations. Genotype determination coefficient effects allow us to infer that characteristics related to seed quality are largely influenced by environmental factors.

Ratio between GCv/GEv was lower than 1.0 for most traits evaluated, except for aging speed test (Table 4). According to Leite et al. (2016), results close to 1.0 for ratio between $\mathrm{GCv} / \mathrm{GEv}$, indicate larger selection perspective. When estimated quotient is greater than or equal to 1, genetic variation available is the largest contributor to variation of experimental data (Mistro et al., 2004). The GCv/GEv ratio can be used as an indicative index of ease degree of genotype selection for each character (Leite et al., 2016).

Genetic variation coefficient $(\mathrm{GCv})$ is an important parameter that allows inferring about magnitude present for a particular character (Ferrão et al., 2008). These values ranged from 1.1 to $21.9 \%$ for all characters presented in this study, which demonstrates existence of variability for evaluated traits (Table 4). Average values to higher for genotypic coefficient of determination and genetic variation are associated to a greater genetic variability, higher selective accuracy and possibility of successfully selecting genotype characteristics (Storck and Ribeiro, 2011).

Soybean genotype selections were obtained through a broad adaptation as proposed by Fox et al. (1997); however, estimated parameter analysis reveals environment influence and also GxE interaction. Thus, genotypes contribution analysis percentage was performed, and for all traits evaluated, GxE interactions were verified and interaction implications in yield parameter and in soybean seed quality. According to Vasconcelos et al. (2012), selection gains can be maximized when performed in a given environment, because GxE interaction is used in process selection.

Genetics and Molecular Research 16 (3): gmr16039801 
Contribution percentage of phenotypic variation effect, that is, genotypes, environments and GxE, was held for trait evaluation in different combinations of sites for 2013/2014 and 2014/2015 seasons. A greater effect of the environment in 2013/14 season was visualized in this analysis (Figure 2), as well as a greater the environment effect on yield, vigor, and viability of seeds by tetrazolium test and mechanical damage by sodium hypochlorite in two seasons cultivation (Figures 2 and 3 ).
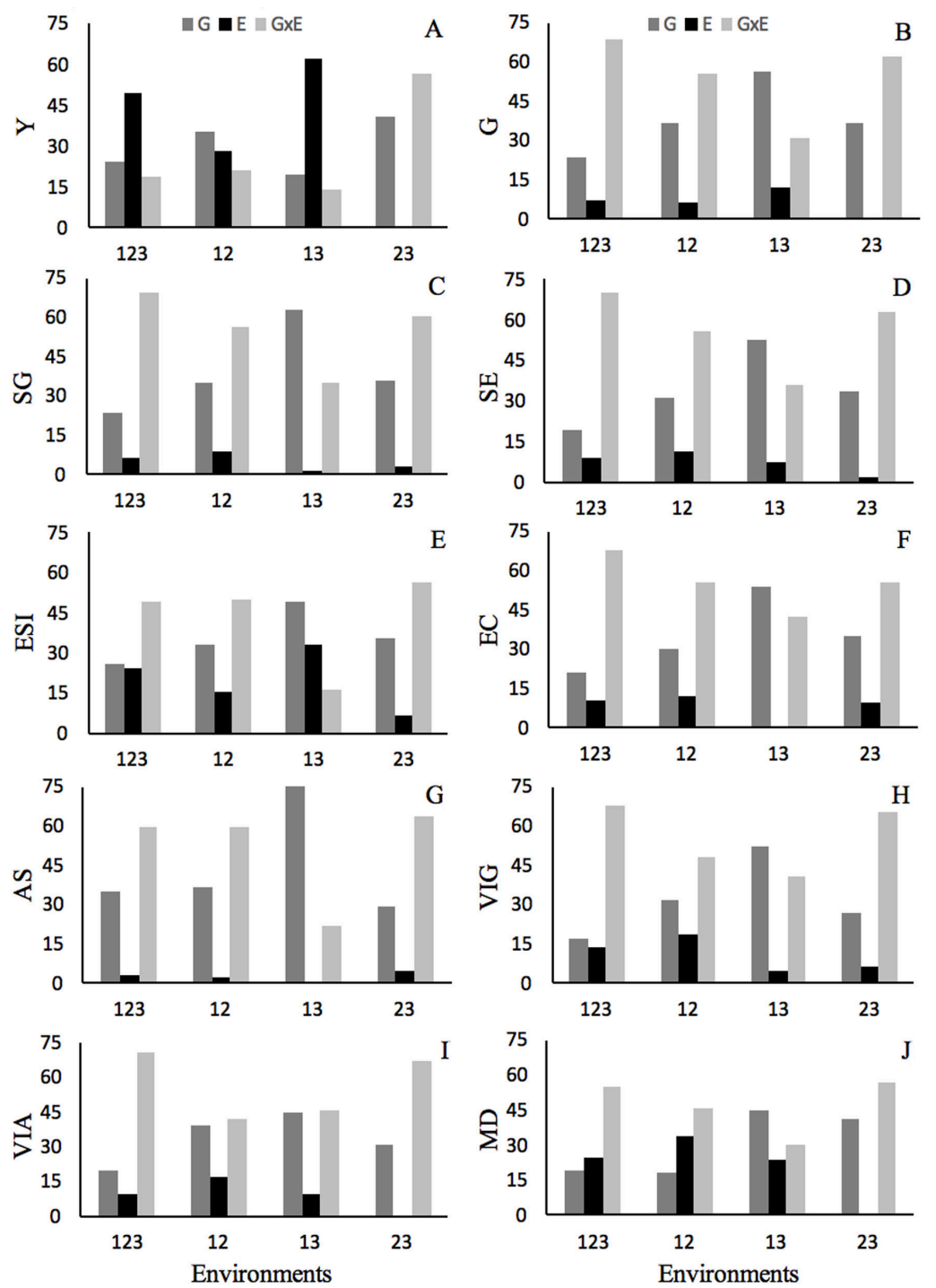

Figure 2. Genotype $(\mathrm{G})$ contribution (\%), environments $(\mathrm{E})$ and interaction $(\mathrm{G} x \mathrm{E})$ in phenotypic variation of yield characters - Y (A), germination - G (B), sand germination - SG (C), seedlings emergence - SE (D), emergence speed index - ESI (E), electrical conductivity - EC (F), aging speed - AS (G), vigor - VIG (H) and viability - VIA (I) of seed, and mechanical damage - MD (J) in soybean seeds produced in Lavras (1), Patos de Minas (2), and Inconfidentes (3) in Minas Gerais State, 2013/14 season, Brazil. 

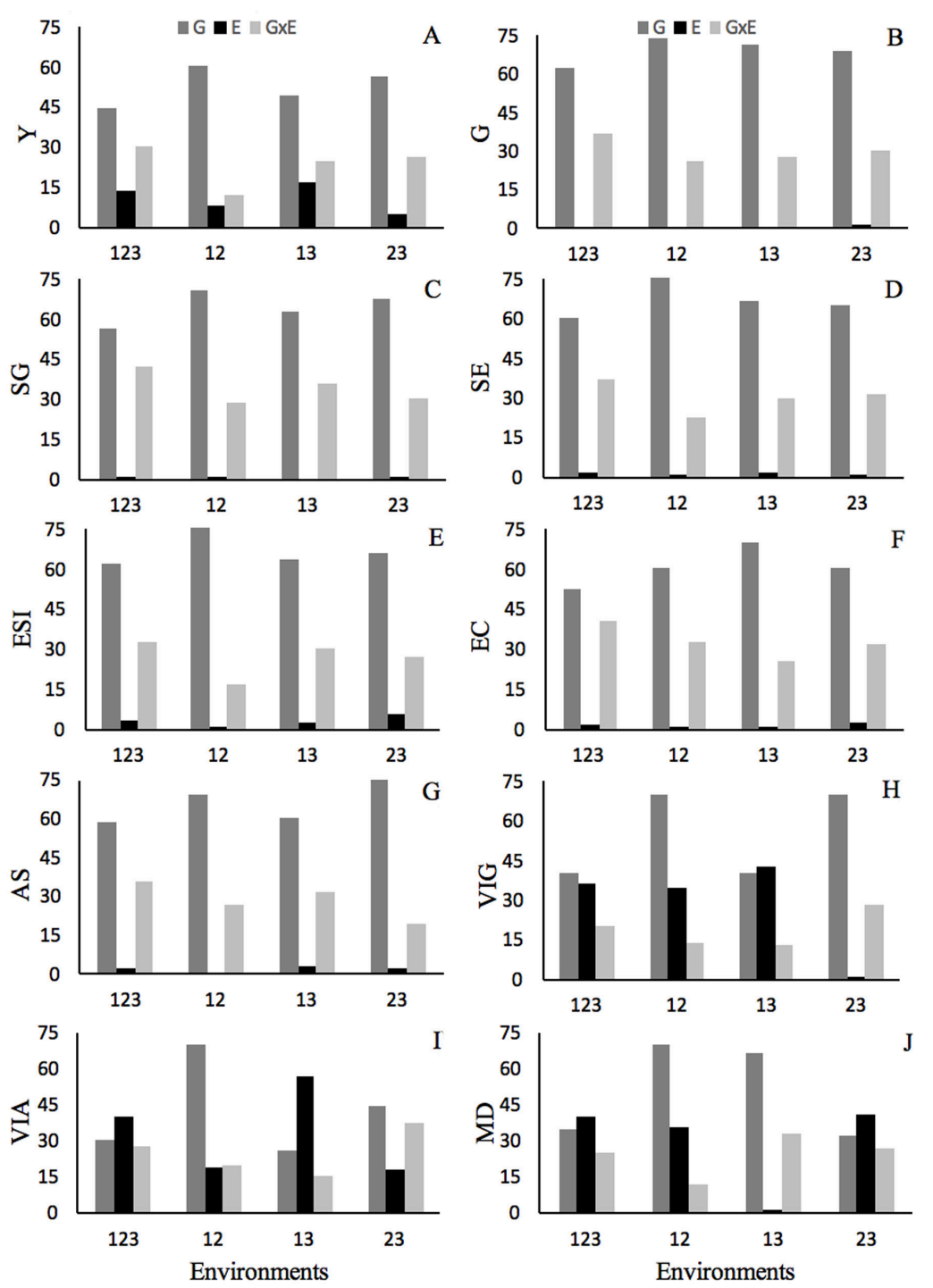

Figure 3. Genotype (G) contribution (\%), environments (E) and interaction ( $\mathrm{Gx} E$ ) in phenotypic variation of yield characters - Y (A), germination - G (B), sand germination - SG (C), seedlings emergence - SE (D), emergence speed index - ESI (E), electrical conductivity - EC (F), aging speed - AS (G), vigor - VIG (H), and viability - VIA (I) of seed and mechanical damage - MD (J) in soybean seeds produced in Lavras (1), Patos de Minas (2), and Inconfidentes (3) in Minas Gerais State, 2014/15 season, Brazil.

According to Allard and Bradshaw (1964), environmental variations can be classified as predictable and unpredictable. Predicable variations include permanent effects, such as soil type, photoperiod and those direct man action, such as seeding time, location, type of fertilization, and harvesting methods. On the other hand, unpredictable changes those which fluctuate inconsistently for example, years, which may vary as rainfall, temperature and relative humidity and pests and diseases incidence (Borém and Miranda, 2009). When genotypes were 
evaluated in greater site numbers, GxE effect interaction is estimated with greater precision and, consequently, contribution is lower of genotypes effect for phenotypic variation (Figures 2 and 3). When genotypes are evaluated in smaller environment numbers, genotype effect is inflated by GxE effects.

For production environments in 2014/2015 season, it appears that most character existence variation was due to genotype effect. This fact can be explained considering the climatic conditions encountered by genotypes were ideal for development of culture and expression of genotypes intensified by lack of environment influence. Greater environmental effect was probably resulted by daily oscillation between environment production in relation to precipitation and temperature in season 2013/14. Thus, to Farias et al. (2007), the climate seems to be one of the most difficult to control and of greater impact on yield and quality of soybean seeds from agricultural production factors, because climate inconsistency is a main risk factor and failure in agriculture exploitation.

Implications of the interaction genotype $\mathrm{x}$ environments are frequently reported in the literature, as example the work conducted by Barros et al. (2010), where complex-type was observed, in other words, there was an inconsistency in genotype performance with environmental variation, making difficult the indication of superior genotypes, which was confirmed by the low values observed, through the parameters studied. Thus, in order to know GxE interaction influence in its expression, we need evaluations and studies directed for quality and seed characteristics.

GxE interaction effects was expressive although genotypes did not present coincidental behavior in different environments. The presence of GxA interaction suggests that the selection of soybean genotypes for seed productivity and quality should be performed at different locations and agricultural years, in order to mitigate this effect in the expression of the characters, since the expression of these characters in their largely due to environmental effects.

\section{CONCLUSION}

Considering genotypes selection of broad adaptation, TMG 1179 RR, CD 2737 RR and CD 237 RR associated better yield performance at high physical and physiological potential of seed.

Environmental effect was more expressive for most of the characters related to soybean seed quality.

GxE interaction effects was expressive although genotypes did not present coincidental behavior in different environments.

\section{REFERENCES}

Allard RW and Bradshaw AD (1964). Implications of genotype environmental interactions in applied plant breeding. Crop Sci. 4: 503-508. https://doi.org/10.2135/cropsci1964.0011183X000400050021x

Barros HB, Sediyama T, Teixeira RC, Fidelis RR, et al. (2010). Adaptabilidade e estabilidade de genótipos de soja avaliados no estado do Mato Grosso. Ceres 57: 359-366. https://doi.org/10.1590/S0034-737X2010000300011

Borém A and Miranda GV (2009). Melhoramento de Plantas. 5th edn. Editora UFV, Viçosa.

Brasil (2009). Regras para análise de sementes. Ministério da Agricultura, Pecuária e Abastecimento - MAPA, Brasília.

Brasil (2013). Padrões de identidade e qualidade para produção e comercialização de sementes. Instrução Normativa $\mathrm{n}$. 45, de 17 de Setembro de 2013.

Castro DG, Bruzi AT, Zambiazzi EV, Rezende PM, et al. (2017). Qualidade fisiológica e expressão enzimática de sementes de soja RR. Rev. Cienc. Agrar. (Lisb.) 40: 222-235.

Genetics and Molecular Research 16 (3): gmr16039801 
Chiorato AF, Carbonell SAM, Vencovsky R, Júnior NSF, et al. (2010). Genetic gain in the breeding program of common beans at IAC from 1989 to 2007. Crop Breed. Appl. Biotechnol. 10: 329-336. https://doi.org/10.1590/S1984$\underline{70332010000400007}$

Costa MM, Di Mauro AO, Unêda-Trevisoli SH, Arriel NHC, et al. (2004). Ganho genético por diferentes critérios de seleção em populações segregantes de soja. Pesqui. Agropecu. Bras. 39: 1095-1102. https://doi.org/10.1590/S0100204X2004001100007

Cruz CD (2005). Princípios de Genética Quantitativa. 1st edn, Editora UFV, Viçosa.

Cruz CD (2013). GENES - a software package for analysis in experimental statistics and quantitative genetics. Acta Sci. Agron. 35: 271-276. https://doi.org/10.4025/actasciagron.v35i3.21251

Embrapa (2013). Tecnologias de produção de soja - Região Central do Brasil 2014. Sistemas de Produção N.16. Embrapa Soja, Londrina.

Faria LC, Melo PGS, Pereira HSP, Wendland A, et al. (2014). Genetic progress during 22 years of black bean improvement. Euphytica 199: 261-272. https://doi.org/10.1007/s10681-014-1135-Z

Farias JRB, Nepomuceno AL and Neumaier N (2007). Ecofisiologia da soja. Embrapa Soja. Circular técnica 48: 1-9.

Fehr WR, Caviness CE, Burmood DT, Pennington JS, et al. (1971). Stage of development descriptions for soybeans, Glycine $\max$ (L.) Merril. Crop Sci. 11: 929-931. https://doi.org/10.2135/cropsci1971.0011183X001100060051x

Ferrão RG, Cruz CD, Ferreira A, Cecon PR, et al. (2008). Parâmetros genéticos em café conilon. Pesqui. Agropecu. Bras. 43: 61-69. https://doi.org/10.1590/S0100-204X2008000100009

Fox PN, Crossa J and Romagosa I (1997). Multi environment testing and genotypes x environment interaction. In: Statistical Methods for plant variety evaluation (Kempton RA and Fox PN, eds.). Chapman and Hall, New York, 117-138.

França Neto JB, Krzyzanowski FC and Henning AA (2010). A importância do uso de semente de soja de alta qualidade. Inf. Abrates 20: 37-38.

França Neto JB (2016). Evolução do conceito da qualidade das sementes. Seed News 20: 5.

França Neto JB, Krzyzanowski FC and Costa NP (1998). O teste de tetrazólio em sementes de soja. Embrapa Soja. Documentos 116: 72.

França Neto JB, Carrão-Panizzi MC, Mandarino JMG, Krzyzanowski FC, et al. (2013). Isoflavone contents in soybean seed subjected to harvest delay. In: Ista Seed Symposium, 119-120.

Gravois KA and Bernhardt JL (2000). Heritability x environment interactions for discoloured rice kernels. Crop Sci. 40: 314-318. https://doi.org/10.2135/cropsci2000.402314x

Krzyzanowski FC (2004). Desafios tecnológicos para a produção de semente de soja na região tropical brasileira. In: Anais do 3 Congresso Brasileiro de Soja, Foz do Iguaçu, 1324-1335.

Krzyzanowski FC, França Neto JB and Costa NP (2004). Teste do Hipoclorito de Sódio para Semente de Soja. Embrapa Soja. Circular técnica $\cdots: 37$.

Leite WS, Pavan BE, Matos Filho CHA, Alcantara Neto F, et al. (2016). Estimativas de parâmetros genéticos, correlações e índices de seleção para seis caracteres agronômicos em linhagens F8 de soja. Comun. Sci. 7: 302-310. https://doi. org/10.14295/cs.v7i3.1176

Maguire JD (1962). Speed of germination-aid in selection and evaluation for seedling emergence and vigor. Crop Sci. 2: 176-177. https://doi.org/10.2135/cropsci1962.0011183X000200020033x

Matos JW, Ramalho MAP and Abreu AFB (2007). Trinta e dois anos do programa de melhoramento genético do feijoeirocomum em Minas Gerais. Cienc. Agrotec. 31: 1749-1754. https://doi.org/10.1590/S1413-70542007000600022

Mistro JC, Fazuoli LC, Gonçalves PDS and Guerreiro Filho O (2004). Estimates of genetic parameters and expected genetic gains with selection in robust coffee. Crop Breed. Appl. Biotechnol. 4: 86-91. https://doi.org/10.12702/19847033.v04n01a14

Monteiro FJF, Peluzio JM, Afférri FS, Carvalho EV, et al. (2016). Correlação entre parâmetros de adaptabilidade e estabilidade em cultivares de soja quanto a produtividade de óleo. Rev. Fac. Agron. 114: 143-147.

Perina EF, Carvalho CRL, Chiorato AF, Gonçalves JGR, et al. (2010). Avaliação da estabilidade e adaptabilidade de genótipos de feijoeiro (Phaseolus vulgaris L.) baseada na análise multivariada da "performance" genotípica. Cienc. Agrotec. 34: 398-406. https://doi.org/10.1590/S1413-70542010000200018

Prado EE, Hiromoto DM, Godinho VDPC, Utumi MM, et al. (2001). Adaptabilidade e estabilidade de cultivares de soja em cinco épocas de plantio no cerrado de Rondônia. Pesqui. Agropecu. Bras. 36: 625-635. https://doi.org/10.1590/ $\underline{\mathrm{S} 0100-204 \mathrm{X} 2001000400005}$

R Development Core Team (2015). R: A language and environment for statistical computing. R Foundation for Statistical Computing, Vienna, Austria. Available at [http://www.R-project.org/].

Ramalho MAP, Ferreira DF and Oliveira AC (2012a) Experimentação em genética e melhoramento de plantas. 3rd edn. Editora UFLA, Lavras.

Genetics and Molecular Research 16 (3): gmr16039801 
Ramalho MAP, Abreu AFB, Santos JB and Nunes JAR (2012b). Aplicações da Genética Quantitativa no Melhoramento de Plantas Autógamas. 1st edn. Editora UFLA, Lavras.

Scott AJ and Knott MA (1974). Cluster analysis method for grouping means in the analysis of variance. Biometrics $\cdots$ : 507-512. https://doi.org/10.2307/2529204

Souza DMG and Lobato E (2004). Cerrado: correção do solo e adubação. 2nd edn. Editora Embrapa, Brasília.

Storck L and Ribeiro ND (2011). Valores genéticos de linhas puras de soja preditos com o uso do método de Papadakis. Bragantia 70: 753-758. https://doi.org/10.1590/S0006-87052011000400004

Valle MLD and Simonetti APMM (2008). Efeito da interação de genótipos x ambiente no desenvolvimento da cultura da soja no estado do Paraná (Glycine max L.). Cultivando Saber 1: 160-170.

Vasconcelos ES, Reis MS, Sediyama T and Cruz CD (2012). Estimativas de parâmetros genéticos da qualidade fisiológica de sementes de genótipos de soja produzidas em diferentes regiões de Minas Gerais. Semin. Cienc. Agrar. 33: 65-76. https://doi.org/10.5433/1679-0359.2012v33n1p65

Zambiazzi EV, Bruzi AT, Carvalho MLM, Soares IO, et al. (2014). Potassium fertilization and physiological soybean seed quality. Agric. Sci. 5: 984-991.

Genetics and Molecular Research 16 (3): gmr16039801 